\title{
Dağın Öteki Yüzü: Sûfî Tefsirde Dağ Metaforu
}

The Other Side of the Mountain: Mountain Metaphor in Sufi Exegesis

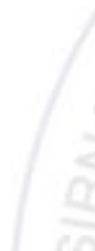

\begin{abstract}
Ahmet GÜL
Dr. Öğr. Üyesi, Şırnak Üniversitesi, İlahiyat Fakültesi, Tefsir Anabilim Dalı Assistant Professor, Şırnak University, Faculty of Divinity, Department of Tafsir Şırnak, Turkey agul 47@hotmail.com https://orcid.org/0000-0001-6822-6581
\end{abstract}

\section{Makale Bilgisi / Article Information}

Makale Türü / Article Types: Araştırma Makalesi / Research Article

Geliş Tarihi / Received: 28 Temmuz / July 2020

Kabul Tarihi / Accepted: 7 Ekim / October 2020

Yayın Tarihi / Published: 15 Aralık / December 2020

Cilt / Volume: 11 Say1 / Issue: 25 Sayfa / Pages: 512-532

Atıf / Cite as: Gül, Ahmet. "Dağın Öteki Yüzü: Sûfî Tefsirde Dağ Metaforu [The Other Side of the Mountain: Mountain Metaphor in Sufi Exegesis]". Şırnak Üniversitesi İlahiyat Fakültesi Dergisi - Şırnak University Journal of Divinity Faculty 11/25 (December 2020), 512-532. https://doi.org/10.35415/sirnakifd.774766

Etik Beyanı / Ethics Declaration: Bu makalede bilimsel araştırma ve yayın etiği ilkelerine riayet edilmiştir. Makale etik izin gerektirmeyen bir çalışma olup en az iki hakem tarafından incelenmiş ve intihal içermediği teyit edilmiştir./ In this article, the principles of scientific research and publication ethics are respected. The article is a study that does not require ethical permission. It has been reviewed by at least two referees and was confirmed that it did not contain plagiarism.

Copyright ( ) Published by Şırnak Üniversitesi, İlahiyat Fakültesi / Şırnak, Türkiye (Şırnak University, Faculty of Divinity, Şırnak, 73000 Turkey). 


\title{
Öz
}

Kur'an-1 Kerim'de yerkürenin çalkalanmadan yerinde durabilmesi için yeryüzüne çakılan kazıklar olarak nitelenen dağların birer denge unsuru olarak yaratıldıkları bildirilmektedir. Birer denge unsuru olmakla birlikte dağlar, doğal su depoları işlevini görmeleri, içlerinde birçok doğal zenginlik barındırmaları nedeniyle insan yaşamına maddi anlamda da değer katmış, önemli bir role sahip olmuşlardır. Taşıdıkları manevi değerle de dağlar dinler tarihinde de önemli bir fonksiyona sahiptir. Birçok dini gelenekte kutsalın merkezi kabul edilen dağlar, vahyin indiği mistik mekânlardır. Ayrıca tanrının tecelli ettiği ilahi güçle donatılmış yerler olarak görülmektedirler. Gücün ve ihtişamın sembolü olan dağlar, yükseklik ve yücelikleriyle Allah'ın azametini vurgulayan güç olarak tezahür etmekte; insanın kibrini kırma noktasında örnek olarak gösterilmektedir. Bunun dışında Kur'ân'da başka özellikleriyle anılan dağlara emanet arz edilmiş, fakat onlar bunu reddetmişlerdir. Kur'an'ın indirilmesinden de haşyet ve korku duymuşlardır. Hz. Musa dağda vahye mazhar olmuş, Allah'la sözleşme yeri olarak kendisine dağ mekân seçilmiştir. Kezâ Hz. Peygambere dağ ilk vahyin ev sahipliğini yapmıştır. Allah'ın azametinin sembolü olan dağlar Kur'ân'da farklı bağlamlarda çeşitli kelimelerle nüans oluşturacak şekilde kullanılmıştır. Dağların mezkûr bu özellikleri onlarla ilgili ayetlerin anlaşılmasında metaforik yorumların oluşmasını beraberinde getirmiştir. Bu makalede Kur'ân'da dağın kavramsal alanı ve sûfî tefsîrde kendini tebarüz ettiren metaforik yorumlara yer verilecektir.

Anahtar Kelimeler: Tefsir, Sûfî Tefsir, Metafor, Dağ, Tûr.

\begin{abstract}
In the Qur'an, it is reported that the mountains, which are described as piles that nailed the Earth for the earth to stand still without shaking, were created as balance elements. In addition, to that, mountains have added material value to human life and have an important role because they function as natural water tanks and contain many natural riches in them. Mountains have an important function in the history of religions with the spiritual value they carry. The mountains, which are considered as sacred centers, also stand out as the places where revelation descends. They are also seen as places endowed with divine power manifested by God. The mountains, which are the symbol of power and Glory, are manifested as the power that emphasizes the greatness of Allah with their height and glory and are shown as examples at the point of breaking man's arrogance. Except for this, the mountains, which are mentioned in the Qur'an in other features, were offered trust, but they refused to undertake it being afraid thereof. They felt awe and feared from the revelation of the Qur'an. Moses was honored with revelation on the mountain, and the mountain was chosen for him as a place of the covenant with Allah. Likewise, the mountain hosted the first revelation to the Prophet. The mountains, which are the symbol of Allah's greatness, have been used in the Qur'an to form nuance with various words in different contexts. These mentioned features of the mountains brought about the formation of metaphorical interpretations in the understanding of the verses about them. In this article, the conceptual area of the mountain in the Qur'an and the metaphorical interpretations that make themselves clear in the Sufi explanation will be given.
\end{abstract}

Keywords: Tafsir, Sufi Exegesis, Metaphor, Mountain, Tûr. 


\section{Extended Abstract}

In the Qur'an, it is reported that the mountains, which are described as piles that nailed the Earth for the earth to stand still without shaking, were created as balance elements. In addition to that, mountains have added material value to human life and have an important role because they function as natural water tanks and contain many natural riches in them. Mountains have an important function in the history of religions with the spiritual value they carry. The mountains, which are considered as sacred centers, also stand out as the places where revelation descends. They are also seen as places endowed with divine power manifested by God.

The mountains, which are the symbol of power and Glory, are manifested as the power that emphasizes the greatness of Allah with their height and glory and are shown as examples at the point of breaking man's arrogance. Except for this, the mountains, which are mentioned in the Qur'an in other features, were offered trust, but they refused to undertake it being afraid thereof. They felt awe and feared from the revelation of the Qur'an. Moses was honored with revelation on the mountain, and the mountain was chosen for him as a place of the covenant with Allah. Likewise, the mountain hosted the first revelation to the Prophet. The mountains, which are the symbol of Allah's greatness, have been used in the Qur'an to form nuance with various words in different contexts. These mentioned features of the mountains brought about the formation of metaphorical interpretations in the understanding of the verses about them. In this article, the conceptual area of the mountain in the Qur'an and the metaphorical interpretations that make themselves clear in the Sufi explanation will be given.

In the Qur'an, the word mountain is generally expressed in the words jebel, ravasi, and tur. While the word jebel contains greatness, splendor, and sublimity in its circle of meaning, it also describes the power and standing strong through metaphor. Besides, mountains are shown as an example of the power and greatness of Allah, so that humankind will not be arrogant. When talking about mountains, people are asked to see them as examples; it is emphasized that they are the work of the power and strength of the supreme creator of the universe.

The word ravasi refers to standing firm and steady. In this sense, the mountains are elements of balance to prevent the earth from shaking and destroying everything on it; they almost act as anchors on ships.

The word tur, which means mountain, also exemplifies the Holy Mountain motif, it is a theme as one of the fertile places where revelation is manifested, and it is separated from its species in this aspect. By containing the meaning of change and transformation, it combines in a common denominator and meaning with the change and transformation that revelation brings to human life.

The words jebel and ravasi, which are used to refer to the mountain in the Qur'an, stand out more with their physical and material meanings, while the words tur and rabiye show the spiritual aspect of the mountains as well as their material benefits.

In Sufi exegesis, the word mountain as a spiritual direction has acquired metaphorical meanings. As the place where divine revelation is manifested, an analogy has been established between the mountain and the heart of Muhammad and has become an expression of it. As a symbol of greatness and height, the mountain has been promoted as the place reached by Salik (pilgrim). In addition, a similarity has been established between the mountain and nur-u Muhammadî, which is one of the important concepts of Sufism, 
which is believed to have been created from the fayd of all believers. The face of man has been suggested as the place where the Jamal of Allah is manifested.

Kaf Mountain, shown as the mother of mountains, is likened to kutbul-aktab. They are likened to him in aspects of glory and unification. Moreover, the inhabitants of the earth can be protected thanks to them. Kaf Mountain is the manifestation of the adjective Kibriya because the mountains represent excellence, human is perfect, too.

As a result, the mountain has acquired new meanings, maintaining its main axis, in parallel with the meanings in both the language and sufi interpretation. These meanings are the product of mystical thought, fictionalized through various analogies, and are obtained by using the metaphorical power of language. 


\section{Giriş}

Dă̆, “türlü iniş çıkışları, kabartı ve çukurları bulunan, çevresindeki alçak yerlere doğru bir etekle sona eren yer; kabarıklıkları veya çevresine göre bir kabartı durumunda bulunan inişli çıkışlı yer biçimidir." ${ }^{1}$ Çevresindeki topraklardan belirgin bir şekilde yükselen bu engebeli şekillerin dinî geleneklerde ayrı ve önemli yerleri vardır. Dünyanın kozmik merkezleri olarak düşünülen dağlar, kutsalın yeryüzüne indiği ve insanlarla bir araya geldiği yerler şeklinde algılanmıştır. Kendilerine ilahi gücün yüklendiğine de inanılan dağlar, hayatın ve ölümün kaynağı olarak da görülmüşlerdir. Dağlar ilhamın, hayalin ve vahyin geliş mekanları olarak bütün dini geleneklerde önemli bir yere sahiptir. Hz. Musa'nın vahiy aldığı ve Allah'la konuştuğu Tûr-i Sînâ, Yahudiler kadar Müslümanlar için mukaddes bir mekân olarak kabul edilmektedir. ${ }^{2}$

Yeryüzünün kuvvet merkezi olarak tasavvur edilen dağlar, yüksek dindarlığın ve ilahi vahyin tecelli ettiği yerler ${ }^{3}$ olarak insanlık tarihinde önemli izler bırakmışlardır. $\mathrm{Bu}$ denli önemi haiz olan dağlara Kur'ân, anlatımlarında bigâne kalmamış, semavî geleneğin içinde mübarek addedilen mekânları, müheymin olması hasebiyle kuşatmıştır. İnsanlığın ve insanoğlunun hayatında kalıcı izler bırakan, yaşam döngüsünde önemli fonksiyonlar icra eden dağlar, Kur'ân'da değişik kavramlarla ifade edilmektedir. Dağların hangi kavramlarla tasvir edildiği ve onları ifade etmek için hangi konseptlerin kullanıldığı öncelikli olarak irdelenecektir. Bu konu başlığında ifade edildiği üzere dağın bir yüzünü oluşturmaktadır. $\mathrm{Bu}$ anlam dünyasından hareketle dağlar hakkında oluşan metaforik anlamlar dağın öteki yüzüdür. Dağın öteki yüzünün ne olduğu, özellikle sûfî tefsirde dağ metaforu makale sinırlarında ele alınacaktır.

\section{Kur'ân'da Dağ Kelimesi ve Anlam Alanı}

Yerkabuğunun üzerinde yükselen taş ve kayalardan oluşan büyük kütleler olan dağlardan Kur'ân'da, birçok ayette söz edilmektedir. Onlardan bahsedilirken, onlara ibret nazarıyla bakılması istenmekte; kâinatının yüce yaratıcısının gücü ve kuvvetinin eseri

1 Reşat İzbırak, Coğrafya Terimleri Sözlü̆̆̈̈̈ (İstanbul: MEB Yayınları, 1992), 79.

2 Diana L. Eck, “Mountain”, Encyclopedia of Religion, ed. Mircea Eliade (New York: Macmillan Publishing Company, 1987) 10/130-134; Mustafa Baş, “Dağ Kültü", Çukurova Üniversitesi İlahiyat Fakültesi Dergisi 13/1 (Ocak-Haziran, 2013), 167-171; Ömer Faruk Harman, “Dağ”, Türkiye Diyanet Vakfı İslam Ansiklopedisi (İstanbul: TDV Yayınları, 1993), 8/400.

3 Ekrem Sarıkçığlu, Din Fenomenolojisi (Isparta: Fakülte Kitabevi, 2002), 19.

4 Yûsuf el-Hâc Ahmed, Mevsuatu el-I'cazu'l-ilmi fi'l-Kur'âni'l-kerim ve's-sunneti'l-mutahharati (Dımaşk: Mektebetu İbn Hacer, 2003), 236. 
oldukları vurgulanmaktadır. Öte yandan insanların hizmetine sunulan dağların, yeryüzünde dengeyi sağlamak ve sallanmasını engellemek hizmetine matuf olarak Allah tarafından yaratıldığı beyân edilmektedir. Kur'ân'da dağı ifade etmek üzere cebel(جبل) -çoğulu cibâl(جبال) kelimesinin yanında Tûr (طور)ve Ravâsî (رواسي) sözcükleri kullanmıştır. Ayrıca daha küçük yükseltileri ifade etmek için râbiye (رابية), kelimesi kullanılmıştır. Dağ ismi olarak da Tûru Sînîn (طور سنين) (Seynâ ), Arafât, Cûdî, Safâ ve Merve tepeleri gibi gibi mukaddes mekanlardan söz edilmiştir. ${ }^{5}$ İlgili kelimelerin geçtiği ayetler ileride belirtildiği için tekrara düşmemek için burada zikredilmeyecektir.

\subsection{Cebel (جبل)}

Sözlükte c-b-1 kelimesi, “yeryüzüne çakılmış büyük kazıklara, sıra halinde yükselen dağa veya doruğa; bir araya gelerek oluşan yükseltiye denmektedir. ${ }^{6}$ Araplar büyük جبل جبلة جبلة cebel; büyük hörgüçleri olan deveye, yüksek ahlaklı kadına da جبلة ceble; yaratılışa, tabiata جبلة cibletu; topluluk veya gruba جبل ceblu demektedir.7

Kur'ân'da cebel altı kez, onun çoğulu cibâl kelimesi otuz dokuz defa geçmektedir. ${ }^{8}$ Kur'ân'da çeşitli bağlamlarda kullanılan dağ kelimesi kullanımları itibariyle farklı anlamlar içermektedir. Dağ/lar şu bağlamlarda zikredilmiştir: Hz. Nuh için esenlik, selamet; müşrikler için helâk, ölüm olan dağ gibi dalgalar;' Semûd kavminin maharet ve ustalıkla yontarak güven ve rahat içinde yaşadıkları evler;10 Hz. Musâ'nın ru'yet hali;"11 Allah'ın yeniden diriltme gücünü Hz. İbrahim'e gösterdiği dağ; ${ }^{12}$ İsrail oğullarının Allah’ın emir ve şeriatini kabul ettikleri yer; ${ }^{13}$ geçmiş topluluklarının hilekârlık ve tuzaklarından dolayı yerinden oynayacak dağlar; ${ }^{14}$ şifa olan balı yapmak için balarısının bal yapmaya gittiği, mesken

5 Ahmet Gül, Kur'an'da Kutsallık (Saarbrücken: Türkiye Alim Kitapları, 2014), 243-247.

6 Halîl b. Ahmed el-Ferâhîdî, Kitâbu'l-'Ayn, thk. Abdulhamîd Hindâvî (Beyrut: Dâru'l-Kutubi'l-İlmiyye, 2003), 1/216; Ebû'l-Huseyn Ahmed b. Fâris, Mekâyîsu'l-luğa, thk. Abdusselam Muhammed Hârûn (Beyrut: Dâru'lFikr, 1979), 1/502; İbn Manzûr, Ebü'l-Fazl Cemâlüddîn Muhammed b. Mükerrem b. Alî b. Ahmed el-Ensârî. Lisânü'l-'Arab, thk. Abdullah Ali-Muhammed Ahmed- Hâşim Muhammed (Kâhire: Dâru'1-Meârif, ts.), 7/537.

7 Ferâhîdî, Kitâbu'l- Ayn, 1/216; İbn Fâris, Mekâyîsu'l-luğa, 1/502; İbn Sîde, Ebu'l-Hasen Alî b. İsmâîl ed-Darîr elMürsî, el-Muhkem ve'l-muhîtu'l-azam, thk. Abdulfettâh es-Seyyid Selîm- Faysal el-Hafyân (Kahire: Ma'hedu'lMahtutâti'l-Arabiyye, 2003), 7/307-308; Muhammed b. Ebî Bekr b Abdulkadir er-Razî, Muhtâru's-sihâh (Beyrut: Mektebetu Lubnân, 1986), 39; İbn Manzûr, Lisânü'l-'Arab, 7/538.

8 Muhammed Fuâd Abdulbâki, el-Mu'cemu'l-mufehres lî elfâzi Kur'âni'l- kerîm (Kâhire: Dâru'l-Hadîs, 1364h), 163164.

9 Bk. Hûd 11/43.

10 Bk. el-Hicr 15/82; eş-Şuarâ 26/149.

11 el-A'râf 7/143.

12 el-Bakara $2 / 62$

13 el-A'râf 7/171.

14 İbrahim 14/66. 
tuttuğu dağlar;, ${ }^{15}$ barınak ve sığınak olan dağlar;, ${ }^{16}$ düşüncesizlik yapıp kibre kapılmanın gereksizliği, bu yüzden yücelik bakımından dağlara ulaşılamayacağı ;17 $^{17}$ kıyamet gününün zorluğundan sarsılan dağlar; ${ }^{18}$ maslahat gereği zorbalara ve Allah'a çocuk isnat edenlerden dolayı göçmek üzere olan dağlar; ${ }^{19}$ haklarında soru sorulan dağlar; ${ }^{20} \mathrm{~Hz}$. Davud'la birlikte tesbih eden dağlar; ${ }^{21}$ Allah'a boyun eğen, ona secde eden dağlar; 22 soğuk ve bulut dağlar1; ${ }^{23}$ kıyamet günündeki dehşet ve şaşkınlığı belirtmek için durumlarından bahsedilen dağlar; ${ }^{24}$ kendilerine emanet arz edilen dağlar; ${ }^{25}$ k1yamet gününde ufalanıp toz bulutu haline gelen, ${ }^{26}$ kaldırılan, ${ }^{27}$ atılmış renkli yüne dönen dağlar;28 sağlam ve sabit bir şekilde duran dağlar; ${ }^{29}$ tevhid ehline delil olarak sunulan dikilmiş dağlar. ${ }^{30}$ Aynı şekilde dağlar, un ufak olma, ${ }^{31}$ çekinme, ${ }^{32}$ Allah'tan korkma ${ }^{33}$ gibi özellikleriyle de anılmaktadır. ${ }^{34}$

Kur'ân'da dağların yaratılış özelliği olarak yeryüzüne çakılı kazık veya sütun olmaları gösterilmiştir. Ayette "Dağları da (yeri tutan) kazıklar yapmadık mı?"35 buyrularak bu duruma dikkat çekilmiştir. Ayete müfessirler şu şekilde yorum getirmişlerdir. Mukâtil b. Süleymân (ö. 150/767), “bir döşek ve beş yüz yıllık yürüme mesafesinde yeri yaygı olarak yaratmış, dağları yeryüzünün sâkinlerinin zeval bulmamaları için yaratmış, yer de sübut bulmuştur. Dağlar yeryüzünden sonra yaratılmıştır."36 Taberî (ö. 310/923), "yerleri döşek

15 en-Nahl 16/ 68.

16 en-Nahl 16/ 81.

17 el-İsrâ $17 / 37$.

18 el-Kehf 18/47; et-Tûr 52/10

19 Meryem 19/90.

20 Taha 20/105.

21 el-Enbiyâ 21/79; es-Sebe 34/10.

22 el-Hacc 22/18.

23 en-Nûr 24/43.

24 en-Neml 27/88

25 el-Ahzâb 33/72.

26 el-Vâkı 56/5.

27 el-Hâkka 69/14.

28 el-Kâria 101/5.

29 en-Nâziât 79/32.

30 el- Ğâşiye 88/19; bk Mecduddîn Muhammed b. Ya'kûb b. Muhammed el-Fîrûzâbâdî, Besâiru zevi't-temyîz fî letâifi'l-kitâbi'l-azîz, thk. Muhammed Alî en-Neccâr (Kahire: el-Meclisu'l-Ấlâ li Şuûni'l-İslamiyye, 1996/1416), 2/362-364.

31 el-A'râf $7 / 143$.

32 el-Ahzâb 33/72.

33 el-Haşr 59/11.

34 Fîrûzâbâdî, Besâiru zevi't-temyîz, 2/364.

35 en-Nebe 78/6.

36 Mukâtil b. Süleymân, Tefsîru Mukâtil b. Süleymân, thk. Abdullah Mahmûd Şehhâte (Beyrut: Muessesetu Tarîhu'l-Arabî, 2002), 4/560. 
olarak sermiş, dağları sizi sarsmaması için kazık olarak yere çakmıştır." ${ }^{37}$ Zemahşerî (ö. 538/1144), “evi sütunları nasıl sağlam tutuyorsa yer de sabit bir şekilde dursun diye dağları kazık gibi çakmıştır." ${ }^{38}$ Râzî (ö. 606/1210), “dağlar, yeryüzündekiler sarsılmasın, yeryüzü, sakinlerine mükemmel bir beşik olsun diye yerin kazıkları olarak yaratılmıştır."39 Kurtubî (ö. 671/1273), “dağlar yer dursun, çalkalanmasın, üzerindekileri başka yere sürüklemesin" 40 diye yaratılmıştır. İbn Kesîr (ö. 774/1373), “dağları yere kazık yapmış, onu içindekileri sarsmasın, dursun ve sabit kalsın diye yaratmıştır."41 Suyûtî (ö. 911/1505), “dağlar yer hareket etmesin, sarsılmaktan kurtulsun diye kazık olarak ona çakılmıştır." 42 Yukarıdaki yorumlardan anlaşılacağı üzere dağların yeryüzüne kazık olarak çakıldığı اوناد evtâd kelimesiyle ifade edilmiştir. Veted وتد kelimesinin çoğulu olan evtâd اوناد çadırı tutan, yere çakılan kazık anlamına gelmektedir. Bunun görünen kısmı olmakla birlikte görünmeyen kısmının daha çok olduğu, içeri gömülen kısmının evi veya çadırı sağlamlaştırdığı kaydedilmektedir. ${ }^{43}$

Bilimsel açıdan bakıldığında kendini çevreleyen yapılardan daha yüksek olan dağların yer altında kalan kısımlarının gözle görülen kütlelerinden fazla olduğu tespit edilmiştir. Bu gerçek ancak on dokuzuncu asrın ikinci yarısından sonra keşfedilebilmiştir. Buna göre, dağların görünen kısmından daha fazlası, yaklaşık on beş katı yeraltında kalmakta bu sayede yerin sarsılmasını ve çalkalanmasını engellemektedir. ${ }^{44}$ Kur'an bu ilmi gerçeği evtâd lafzıyla asırlar önce ümmi bir peygamberin dilinden bildirmiştir.

Kur'ân'da cebel kelimesi üç farklı anlamda kullanılmıştır. Bunlardan ilki soğuk olmak veya bir yağış türü olan dolu anlamındadır. “Oradaki bulut dağlarından dolu yağglırır da bunu dilediğine isabet ettirir, dilediğinden de onu uzaklaştırır"45 ayetinde geçen برد bered kelimesi

37 Ebû Cafer Muhammed b. Cerîr Taberî, Câmiü'l-beyân an tévili ayi'l-Kur'ân thk. Abdullah Abdulmuhsin et-Turkî (Kâhire: Hicr, 2001), 24/8-9.

38 Ebu'l-Kasım Mahmûd b. Ömer b. Muhammed ez-Zemahşerî, el-Keşşâf hakâiki ğavâmizi't-tenzîl ve uyûni'l-ekâvîl fî vücûhi't-tevîl, thk. Adil Abdulmevcûd- Ali Muhammed el-Muavvid (Riyâd: Mektebetu Ubeykân, 1998), 6/295.

39 Fahruddîn Muhammed b. Ömer er-Râzî, Mefâtîhu'l-Gayb (Beyrut: Dâru'1-Fikr, 1981), 32/7.

40 Ebû Abdillah Muhammed b. Ahmed Kurtubî, el-Câmi li-ahkâmi'l-Kurân, thk. Abdullah b. Abdulmuhsin etTurkî (Beyrut: Muessesetu'r-Risâle, 2006) 22/7.

41 Ebu'l-Fidâ' İsmâîl b. Ömer b. Kesîr, Tefsîrü'l-Kurâni'l-azîm, thk.Mustafa Seyyid Muhammed vd. (Ciza: Muessesetu Kurtubâ, 2000), 14/227.

42 Suyûtî, Celâlüddîn Abdurrahmân b. Ebî Bekr b. Muhammed, ed-Durru'l-mensûr fi't-tefsîr bi'l-me'sûr, thk. Abdullah b. Abdulmuhsin et-Turkî. (Kahire: Hicr, 2003), 15/191.

43 Abdullah b.Abdulaziz el-Muslih- Abdulcevad es-Savî, el-I'cazu'l-ilmî fi'l-Kur'ân ve's-sunne, (Cidde: Darû Ciyâd, 2008/1429), 188

44 Yûsuf el-Hâc, Mevsuatu'l-i'cazu'l-ilmî, 236-238; el-Muslih-es-Sâvî, el-í'cazu'l-ilmî,188-189.

45 Kur'an Yolu (Erişim 15 Haziran 2020), en-Nûr 24/43. 
soğuk dağlar veya dolu anlamında kullanılmıştır. Bakara Sûresi 260. ayetinde geçen كل جبل ifadesi dört dağ; A'raf Sûresi 171. ayetindeki جبال kelimesi bütün dağlar anlamındadır. ${ }^{46}$

Dağ, kelime manası baz alınarak istiare yoluyla kullanılmış; ondan bazı kelimeler türetilmiştir. Dağlara ait bazı özellikler insanlar için de kullanılmaktadır. Dağ gibi adam benzetmesinde adamın sağlam duruşu ve kararlılığından, sebatından söz edilmektedir. ${ }^{47}$

Kur'ân'da c-b-1 kökü sözlük anlamlarından olan dağ, ${ }^{48}$ ve topluluk ${ }^{49}$ anlamlarıyla kullanılmıştır. C-b-1 kökünün türevlerinin odak anlamı yukarıdaki örneklerden anlaşılacağı üzere büyüklük, katılık ve sertliktir. Zira dağ, yücelik, büyüklük, sağlamlığından, topluluk; gücü kuvveti ve büyüklüğü olduğundan bu şekilde adlandırılmıştır. ${ }^{50}$

\subsection{Ravâsî (رواسي)}

R-s-v رسو sözlükte konunun bir yönünü anlatmak, sözü kendi içinde tutmak, dağın kökünün sübut bulması, geminin demir atması anlamlarına gelmektedir. ${ }^{51}$ Rusuv رسو uzun bir yolculuktan sonra ağır bir şeyin deniz kenarında durmasıdır. ${ }^{52}$

R-s-v kökü Kur'ân'da türevleriyle birlikte on dört defa geçmektedir. Bunlardan dağları ifade etmek üzere dokuz kez رواسي ravâsî; kazanların büyüklüğünü ifade etmek için de bir defa راسيات râsiyât şeklinde geçmektedir.53

R-s-v kökü Kur'ân'da iki anlamda kullanılmıştır. Bunlardan ilki, yerin sarsılmaması,

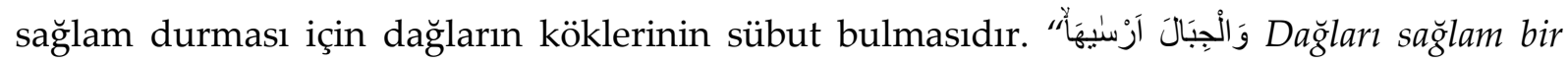
şekilde yerleştirdi." 54 ayetinde geçtiği üzere Allah, yer sarsılmasın diye onları sağlam bir

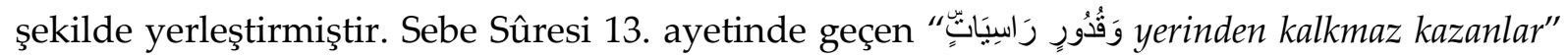
ifadesi de kazanların büyüklüğünün yanında sabit oluşları ifade edilerek sağlamlık ve

46 el-Kebîsî, Mevsûatu'l-kelimeti, 2/420-421.

47 Râgıb el-İsfahânî, Ebu'l-Kâsım Huseyn b. Muhammed b. el-Mufaddal, Mufredâtu elfâzi'l-Kurân, thk. Safvân Adnân Davudî (Dımaşk: Dâru'l-Kalem, 2009), 185; Fîrûzâbâdî, Besâiru zevi't-temyîz, 2/365.

48 el-Bakara 2/260; el-A'râf 7/143, 171; Hûd 11/43; el-Haşr 59/21.

49 Bk.Yâsîn 36/62; Şuarâ 26/184.

50 Ebû Hilâl el-Askerî, el-Furûku'l-luğaviyye, thk. Muhammed İbrâhîm Selîm (Kâhire: Dâru'l-i̇lm ve's-Sekâfe, 1997), 276; Muhammed Hasen Hasen Cebel, el-Mu'cemu'l-iştikâkîyyi'l-muassal li elfâzi'l-Kur'âni'l-kerim (Kâhire: Mektebetu'l-Âdâb, 2010), 273; Ahmed Ubeyd el-Kebîsî, Mevsûatu'l-kelimeti ve ehavâtihâ fi'l-Kur'âni'l-kerim (Beyrut: Dâru'l-Marife, 2017/1438), 2/420.

51 Ferâhîdî, Kitâbu'l-'Ayn, 2/118; İbn Fâris, Mekâyîsu'l-luğa, 2/394-395; Râgıb el-İsfahânî, el-Mufredât, 354; İbn Manzûr, Lisânü'l-'Arab, 17/1648.

52 el-Kebîsî, Mevsûatu'l-kelimeti, 5/166.

53 Abdulbâki, el-Mu'cemu'l-mufehres, 320.

54 en-Naziât 79/32. 
sabitlik vurgusu yinelenmiştir. ${ }^{55}$ İkinci olarak bu kökten türemiş kelimelerin Kur'ân'da

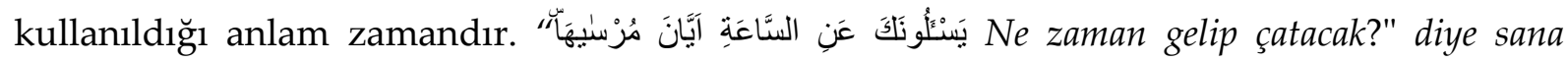
kıyamet saatini sorarlar" ${ }^{56}$ ayetinde kıyametin ne zaman kopacağ 1 sorusu sorulmuş, burada

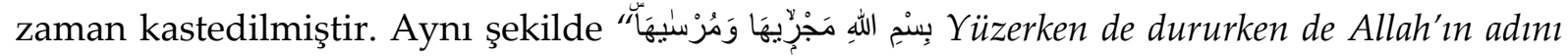
$a n ı n^{\prime \prime 5}$ ayetinde de zaman vurgusu yapılmıştır. ${ }^{58}$

“...sizi sarsmaması için yere sağlam dağlar yerleştirdi..."59 ayeti, yerin insanları sarsmaması için ağır baskılarla ve sabit dağlarla çakıldığını bildirmektedir. Bu sayede yeryüzü canlıların yaşamasına elverişli hale gelmiştir. ${ }^{60}$ Yerkürenin soğuması sonucu içindeki gazların donması ve hacimlerinin azalmasıyla oluşan çıkıntılar olan dağların, hacimlerinin küçülüp büyümesine bağlı olarak yerkabuğu kıvrımlı hale gelmektedir. İçteki büzülmeler neticesinde girinti ve çıkıntılar ortaya çıkmaktadır. Ayet dağların yerin dengesini koruduğunu, bununla sarsılmaktan ve sallanmaktan kurtulduğunu belirterek yerdeki gazların kasılıp büzülmesi sonucu oluşacak çöküntünün girinti çıkıntılarla yani dağlarla dengelendiğini ifade etmektedir. ${ }^{61}$

Jeologlara göre, dağların yerkabuğunun üzerinde yükselerek yaratılması ilka (atılma veya yerleştirme) yoluyla gerçekleşmiştir. $\mathrm{Bu}$, jeolojik olarak uzun asırlar sürmüştür. Okyanuslardaki volkanların aşağıdan yukarıya tektonik hareketleri; yukarıdan aşağıya doğru hareketlerden dolayı nehir ve büyük kayaların çökmesini beraberinde getirmiş; yerkabuğunun altındaki hareketlerin onu baskılaması sonucu dağlar oluşmuştur. Volkanik dağlar yeraltındaki volkanların püskürmesi sonucunda oluştuğu gibi renkli dağlar okyanuslardaki derin çukurların, kayaların dolması ve bunların kıyıda yükselmesiyle meydana gelmiştir.62 Kur'an bunu "Arzı da yaydık, oraya sağlam dağlar yerleştirdik";63 "O, sizi sarsmaması için yere sağlam dağlar yerleştirdi";64 "sizi sarsmaması için yere sağlam dă̆lar

\footnotetext{
55 Muhammed Tâhir b. Aşûr, et-Tahrîr ve't-Tenvîr (Tûnus: ed-Dâru't-Tûnusiyye, 1984), 22/163; el-Kebîsî, Mevsûatu'l-kelimeti, 5/168.

56 el-A'râf 7/187.

57 Hûd 11/41.

58 Fîrûzâbâdî, Besâiru zevi't-temyîz, 3/74; el-Kebîsî, Mevsûatu'l-kelimeti, 5/168.

59 Lokmân 31/10.

60 Râzî, Mefâtîhu'l-Gayb, 25/144; Alûsî, Ebû's-Senâ Şehâbeddîn Mahmûd b. Abdullâh b. Mahmûd, Ruhu'l-meân $f \hat{i}$ tefsîri'l-Kur'âni'l-âzim ve's-seb'i'l-mesânî, thk. Mâhir Habbûş (Beyrut: Muessesetu'r-Risâle, 2010), 21/81.

61 Seyyid Kutub, Fî Zilâli'l-Kur'ân (Kâhire: Dâru'ş-Şurûk, 2003), 5/2786.

62 Z.R. el-Naggar, The Geological concept of mountain in the Qur'an (Cairo: Al-Falah Foundation, 2003/1424), 34-35; Zağlûl en-Neccâr, Tefsîru'l-ayâti'l-kevniyyeti fi'l-Kur'âni'l-kerîm (Kâhire: Mektebetu'ş-Şurûk ed-Duveliyye, 2007/1428), 1/472-473; Yûsuf el-Hâc, Mevsuatu'l-i'cazu'l-ilmî, 239.

63 el-Hicr 15/19.

64 en-Nahl 16/15.
} 
yerleştirdi"65 ayetleriyle bildirmektedir. Dünyanı kendi ekseninde hareket ederken aşırı sallanması, derinlere sağlam bir şekilde kök salan dağlar sayesinde sübut bulmakta, böylece üzerindekileri fırlatmamaktadır. Ayette geçen رواسي ravâsî kelimesi bunu anlatmaktadır. ${ }^{66}$ Ayetlerde sağlam dağlar yerleştirildiğinin bildirilmesi dağların etkileyici ve haşmetli yapılarının ilahî kudretin tecellisini yansıttı̆̆ını göstermesi bakımından önemlidir. Ayrıca dağlar insanlar ve diğer canlıların yaşaması için uygun şartların oluşmasında önemli bir role sahiptir. Ayetlerde buna işaret vardır. ${ }^{67}$

Ayetlerden de anlaşılacağ1 üzere رسو kökünün odak anlamı sağlam olmak; içine veya altına girerek bir şeyi sağlam tutmaktır. ${ }^{68}$ Netice itibariyle dağlar, yeryüzüne ilkâ edilmiş, bu sayede yeryüzü sağlam ve dengeli bir yapıya kavuşmuştur. Kur'an bunu ravâsî kelimesi ile ifade etmiş, bilimsel bir gerçeği asırlar öncesinden haber vermiştir. ${ }^{69}$

\subsection{Tûr (طور)}

Sözlükte zamanda veya mekânda uzunluk anlamindaki t-v-r طور kökünden türeyen tûr istiare yoluyla enine ve boyuna uzayan dağın özel ismi olmuştur. Tûr dağ anlamına gelmektedir. Evcil olmayan, yabani hayat yaşayan canlılara, ünsiyetten uzak kaldıkları için tûri طور tûranî denilmektedir.70 Kelimenin Süryânîce veya Nabâtça olduğu iddia edilse $\mathrm{de}^{71}$ bu dillerin Sâmî dil grubundan olması, kelimenin Arapça kökünün olması, onun muarreb olmasını gerektirmemektedir. Yukarıda zikredilenler bunu destekler mahiyettedir. Tûr, üzerinde bitki biten dağı ifade etmekte; cebel ise aksine ot bitmeyen sarp engebeli araziyi ifade etmektedir. ${ }^{72}$

65 Lokman 31/10.

${ }^{66}$ Neccâr, Tefsîru'l-ayâti'l-kevniyyeti, 1/475; Muhammed Râtıb en-Nâblusî, Mevsûatu'l-i'cazu'l-ilmî fi'l-Kur'ân ve'ssunneti (Dımaşk: Dâru'l-Mektebi, 2005/1426), 142.

67 Bk. Hayreddin Karaman vd., Kur'an Yolu Türkçe Meal ve Tefsir (Ankara: TDV Yayınları, 2012), 3/344.

68 Cebel, el-Mu'cemu'l-iştikâkî, 797.

69 en-Neccâr, Tefsîru'l-ayâti'l-kevniyyeti, 1/475; el-Naggar, The Geological concept of mountain in the Qur'an, 34-35.

70 Ferâhîdî, Kitâbu'l-'Ayn, 3/64; İbn Fâris, Mekâyîsu'l-luğa, 3/430; İbn Sîde, el-Muhkem, 9/190; Râgib el-İsfahânî, elMufredât, 528; İbn Manzûr, Lisânü'l-Arab, 30/2718; Mecduddîn Muhammed b. Ya'kûb b. Muhammed elFîrûzâbâdî, Kâmûsu'l- muhît, (Kahire: Dâru'l-Hadîs, 2008/1429), 1023; Hasîrîzâde Elîf Efendi, en-Nûru'l-Furkân fî şerhi lugati'l-Kur'ân, (İstanbul: Türkiye Yazma Eserler Kurumu Başkanlığg Yayınları, 2015), 2/52.

71 Taberî, Câmiu'l-beyân, 17/30; Celâlûddîn Abdurrahmân b. Ebî Bekr b. Muhammed Suyûtî, el-ïtkân fî ulûmi'lKur'ân, thk. Şuayb Arnâut (Beyrut: Muessesetu'r-Risâle, 2008), 295; Ebû Mansûr Mevhûb b. Ahmed b. Muhammed el-Cevâlîkî, el-Muarreb mine'l-kelâmi'l-acemî alâ hurûfi'l-mucem, thk. F. Abdurrahîm (Dımaşk: Dâru'l-Kalem, 1990/1410), 435; Arthur Jeffery, The Foreign Vocabulary of The Qur'an (Leiden: Brill, 2007), 206-207.

72 Taberî, Câmiu'l-beyân, 2/48,49. 
Tek başına kullanıldığında dağ ve Sînâ dağı anlamında da kullanılan Tûr kelimesi Kur'ân'da on bir kez zikredilmektedir.73 İki yerde terkip halinde Tûriseynâ (طور سيناء) ve Tûrisînîn (طور سنين) 75 şeklinde geçmektedir. Tefsirlerde Filistin veya Şam bölgesinde bulunan dağ şeklinde görüşler yer alsa da Allah'ın Hz. Musa'ya tecelli ettiği ve Hz. Musa'nın vahiy aldığı, münacatta bulunduğu Sînâ Dağı olduğu görüşü daha çok kabul görmektedir. ${ }^{76}$

Yahudi literatüründe Sînâ Dağı Har ha Elohim (Tanrı Dağı), Har Başan, Har Gabnunim, Kedemot, Kadeş ve Paran isimleriyle anılmaktadır. ${ }^{77}$ İbranice'de kuraklık, kuruluk anlamındaki hrb/v kökünden türeyen Horeb/v Sînâ Dağı'nın asıl ismidir. ${ }^{78}$ O, Yahudilikteki kutsal iki dağdan birisidir. ${ }^{79}$ Kur'ân'da "üzerinize de dağı kaldırmıştık." 80 ayetinde geçen Tûr kelimesi dağı ifade etmekle birlikte burada kastedilen mekân Tûrisînîn'dir. Mukaddes bir mekân olan Tûr Dağı Hz. Musa'nın vahiy aldığı Tuva vadisini içerisinde barındırmaktadır. Ayette ahdin gereğini yerine getirmeyen İsrail oğulları üzerine bu dağın kaldırıldığı bildirilmektedir. Dağın üzerlerine kaldırılması yerden sökülüp bulut veya gölgelik haline getirilmesi ${ }^{11}$ veya şiddetli bir şekilde sarsılmasıdır. "Bir zamanlar İsrâiloğulları'nın üzerine dă̆ı bir gölgelik gibi kaldırdık da üstlerine düşecek sandılar" 82 ayeti bunu ifade etmektedir. Ayette geçen neteknâ (نَقَتَنَا) kelimesi salladık, sarstık anlamlarına gelmektedir. Ayette anlatılan hadise dağın üzerine yoğun bir bulut, sis ve dumanla birlikte şiddetli bir sarsıntının meydana gelmesi şeklinde yorumlanmıştır. ${ }^{83}$ Yukarıdakilerden anlaşıldığı üzere Tûr Dağı Yahudilikte önemli mekânlardan birisi olup Kur'ân'ın anlatımları da bunu desteklemektedir.

73 Abdulbâki, el-Mu'cemu'l-mufehres, 429.

74 el-Mu'minûn 23/20.

75 et-Tîn 95/2.

76 Taberî, Câmiu'l-beyân, 17/29-30; 24/507; Ebû Muhammed el-Huseyn b. Mes'ûd b. Muhammed el-Begavî, Meâlimu't-tenzîl, thk. Muhammed Abdullah en-Nahr vd. (Riyâd: Dâru Taybe, 1412),5/414; 8/471; Ebu'1-Hasen Alâuddîn Alî b. Muhammed b. İbrâhîm el-Hâzin, Lubâbu't-tevîl fî meâni't-tenzîl, thk. Abdusselâm Alî Şâhîn (Beyrût: Dâru'l-Kutubi'l-İlmiyye, 2004/1425), 3/270; 4/444; Fîrûzâbâdî, Besâir, 3/518.

77 Max Seligsohn, "Sinai, Mount", The Encyclopedia of Jewish, ed. Isidore Singer (London: Funk\&Wagnalls Company, 1912), 11/381; Mustafa Sinanoğlu, "Sînâ", Türkiye Diyanet Vakfi İslam Ansiklopedisi (İstanbul: TDV Yayınları, 2009), 37/221.

78 Çıkış 33/6;

79 Baruch J. Schwartz, “Sinai Mount”, The Oxford dictionary of Jewish religion, ed. R.J. Zwi Werblowsky (New York: Oxford University Press,1997), 646.

80 el-Bakara 2/63.

81 Taberî, Câmiu'l-beyân, 2/50-51.

82 el-A'raf 7/171.

83 İbn Aşûr, et-Tahrîr ve't-Tenvîr, 1/541; Mustafa Öztürk, İlahî Hitabın Tefsiri (Ankara: Ankara Okulu Yayınları, 2020), 2/430. 
T-v-r kökü Kur'ân'da varlığın zaman veya mekân boyutunda üzerinde bulunduğu durumu, değişim ve dönüşümü ifade etmektedir. Nitekim وَقََْ خَلَكَعْمُ اَطْوَاراً Oysa O sizi türlü evrelerden geçirerek yaratmıştır." 84 ayeti bunu ifade etmektedir. ${ }^{85}$ İnsanın yaratılış safhaları olan, nutfe, alaka, mudğa (çiğnenmiş et), kemik, kemiklere etin giydirilmesi son olarak insan şeklinin verilmesi; ${ }^{86}$ varlığın zaman ve mekân içinde uğradığ 1 değişimi göstermekte ${ }^{87}$ Kur' ân $^{\prime}$ bunu t-v-r kökünden türeyen etvâr (اطوار) kelimesiyle ifade etmektedir.

Netice itibariyle, t-v-r kökü ister dağ ister hal anlamı ifade etsin varlığın zaman ve mekân boyutunda geçirdiği değişimi anlatmaktadır. Tûr Dağının inişli çıkışlı ve engebeli yapısı ve insanın yaratılış aşamasındaki değişimleri bunu göstermektedir.

\subsection{Rabve (ربوة)}

Yerden daha yüksek olan arazi parçalarına, tepeye verilen isimdir. ${ }^{88} \mathrm{R}-\mathrm{b}-\mathrm{v}$ kökü Kur'ân'da şişip yükselmek; ${ }^{89}$ yüksek yer, tepe; ${ }^{90}$ yukarıya çıkmış, suyun üzerinde kalmış; ${ }^{91}$ şiddeti yüksek bir azapla yakalamak ${ }^{92}$ anlamlarında kullanılmıştır. Aynı kökten türeyen ribâ kelimesi de artış ve fazlalık anlamına gelmektedir.

Kur'ân-1 Kerim'de “Meryem oğlu ile annesini de bir mûcize yaptık; ikisini de kalmaya elverişli, kaynak suyu bulunan yüksekçe bir yere yerleştirdik."93 buyrulmaktadır. Mezkûr yüksek yerin Remle, Beytu'l-Makdis, Dımaşk, Nil nehrinin kenarında Mısır'da bir yer olduğu söylenmektedir. Burasının yaşamaya elverişli sulak ve yaylak bir araziye sahip olduğu bildirilmektedir. ${ }^{94}$ Tefsirlerden de anlaşılacağı üzere rabve, bereketli, üzerinde ürünlerin yetiştiği, akarsuyun olduğu, sulak yüksek tepedir. Kelime kökünün artma ve büyümeyi ifade etmesi bunu desteklemektedir.

84 Nûh $71 / 14$.

85 İbn Fâris, Mekâyîsu'l-lŭğa, 3/430; Cebel, el-Mu'cemu'l-iştikâkî, 1318.

86 Mukâtil b. Süleymân, Tefsîru Mukâtil, 4/450; Ebû Hafs Ömer b. Alî b. Âdil ed-Dımaşkî, el-Lubâb fì İlmi'l-Kitâb, thk. Âdil Ahmed Abdumevcûd- Alî Muhammed Muavvid (Beyrût: Dâru'l-Kutubi'l-İlmiyye, 1998/1419), 19/388; el-Kebîsî, Mevsûatu'l-kelimeti, 7/609.

87 Cebel, el-Mu'cemu'l-iştikâk̂̂, 1318-1319

88 İbn Fâris, Mekâyîsu'l-luğa, 2/483; Râgıb el-İsfahânî, el-Mufredât, 340; Fîrûzâbâdî, Besâiru zevi't-temyîz, 3/34; Cebel, el-Mu'cemu'l-iştikâkî, 740.

89 el-Hac 22/5; el-Fussilet 41/39.

90 el-Bakara 2/265; el-Mu'minûn 23/50.

91 er-Ra'd 13/17.

92 el-Hâkka 69/10.

93 el-Mu'minûn 23/50.

94 Taberî, Câmiu'l-beyân, 17/54-58; Muhammed İzzed Derveze, Tefsîru'l-Hadîs (Beyrût: Dâru'l- Ğarbi'l-İslâmî, 2000/1421), 5/315-316. 
Netice itibariyle r-b-v kökünün odak anlamı bir şeyin büyümesi, gelişmesi, yükselmesidir. ${ }^{95} \mathrm{Bu}$ da dağ ve yükseltilerin insan hayatında önemli yeri olan su ve tarım ürünlerinin yetişmesinde ve gelişmesinde etkisi olduğunu göstermektedir. Ayrıca rabve deniz seviyesinden yüksekliği fazla olmadığı için ılıman olması dolayısıyla da ürün çeşitliliğine imkân tanımakta, hayata canlılık katmaktadır.

\section{Sûfî Tefsirde Dağ Metaforu}

Denge unsuru olarak yaratılan dağların çeşitli taş ve kayaçlardan oluştuğu bilinmektedir. Kur'ân-1 Kerim taşların katılık ve sertliklerine rağmen Allah korkusundan yuvarlandığını, içinden suların fışkırdığını bildirmektedir. ${ }^{96}$ Cansız oldukları düşünülen taşların canlı varlıklar gibi tavsif edilmeleri ve onlara insanî eylemlerin izafe edilmesi mecazî anlatım olarak dikkat çekmektedir. ${ }^{97}$ Katılık ve sertliklerine rağmen Allah'tan korkan ve ona itaat eden taşlar gibi dağlar da Kur'ân'da çeşitli bağlamlarda zikredilmiş, mecazın geniş imkânlarına konu olmuştur. Nitekim sûfî tefsirlerde yukarıda dağ hakkında zikredilen anlam alanı genişletilmiştir. Burada sûfîlerin dağlarla ilgili ayetlerin yorumlarına yer verilecektir.

Sülemî tefsirinde dağı, Muhammedî kalb olarak yorumlamıştır. Allah Hz. Muhammed'in kalbini Tûr olarak adlandırmış, diğer peygamberlerin ve evliyanın kalbine Beytu'l-Ma'mûr demiştir. ${ }^{98}$ Zira Allah onların kalplerini yakınlık, müşahede, ilim, hikmet, marifet, vecd, hal ve mükâşefe nuruyla mamur hale getirmiştir. ${ }^{99}$

Dağlar insanın yüzü, Allah'ın cemalinin tecelli ettiği aynadır. Bunu “Tûr'a, açık sahifeler üzerine yazılı kitaba, beytülma'mûra and olsun"100 ayetinin yorumunda görmek mümkündür. Buna göre; Tûr Muhammedî suretle birlikte, babası Ademî sureti de ifade edebilir. Zira Allah onu kendi eliyle yaratmış, ona ruhundan üflemiş, onun varlığının aynası yapmış, ruhunu "Ve Âdem'e bütün isimleri öğretti" ayetinde buyurduğu üzere ilimlerinin sırlarının sayfası yapmıştır. ${ }^{101}$

95 Cebel, el-Mu'cemu'l-iştikâkî, 740.

96 Bk. el-Bakara 2/74.

97 Merve Saçlı, “Bakara Suresi 74. Ayet Bağlamında Taşlar ve Allah Korkusu”, Şırnak Üniversitesi İlahiyat Fakültesi Dergisi 11/24 (Haziran 2020), 330.

98 Muhammed b. Huseyn es-Sulemî, Hakâiku't-tefsîr, thk. Seyyid İmran (Beyrut: Dâru'l-Kutubi'l-İlmiyye, 2001), $2 / 280$.

99 Rûzbihân el-Baklî, Ebû Muhammed Sadrüddîn b. Ebî Nasr, 'Arâîü'l-beyân fî hakâîki'l-Kur'ân, thk. Ahmed Ferîd el-Mizyadî (Beyrut: Dâru'1-Kutubi'l-İlmiyye, 2008), 3/351.

100 et-Tûr 52/1-3.

101 Rûzbihân el-Baklî, 'Arâîü̈'l-beyân, 3/351. 
Sûfî tefsirde vahyi taşıma kabiliyeti açısından dağlar ve peygamberler karşılaştırılmıştır. Dağlar ilahi kelamı olanca cesamet, ağırlık ve azametlerine rağmen taşıma gücünden yoksun olmasına rağmen peygamberler, ilahi kelamı taşıma kabiliyetiyle donatılmışlardır. "Oysa biz onu senin kalbine iyice yerleştirmek için böyle yaptık"102 ayeti kerimesinde belirtilen husus budur. ${ }^{103} \mathrm{Bu}$ da onların şanını ve büyüklügünü göstermesi bakımından önem arz etmekte, gaflete düşen ve uyanık bir kalbe sahip olanlar arasındaki farkı göstermektedir. ${ }^{104}$

Dağlar ilahi vahyin tezahür ettiği yerlerdir. Ayrıca keşf ve ilham sahipleri de burada ilahi tecelliden nasipdâr olmuşlardır. Vahyin tecelli etmesine dayanamayıp un ufak olan dağlara mukabil ariflerin kalpleri Allah'ın esmasının tecelligâhı olmaya elverişlidir. Zira Allah onu o güçte yaratmıştır. ${ }^{105}$ Yerin direği olan dağlar Kur'an'da Tûr olarak da zikredilmiştir. Tûr Hz. Musa'nın Allah'la konuştuğu dağ olmakla birlikte, Allah dostlarının geldikleri yerdir. Birçok evliyâ buraya gelmiş, manevi ahvâl kendisini kuşatmış, ilahi hitaba mazhar olmuştur. ${ }^{106}$

Sûfî tefsirde dağ, sağlamlığın ve azametin sembolü olmasının yanında canlı varlıklar gibi bilinç ve idrak yüklüdür. Bunu kendisine Kur'ân indirilmesi durumunda paramparça olmasından çıkarsamak mümkündür. Katı ve cahil insanın görmezden geldiği, ilahi kelama kulaklarını tıkadığı bu durum karşısında dağlar un ufak olmayla karşı karşıya kalmış, hatta olmuştur. ${ }^{107}$ Kur'an insana eleştiri sadedinde dağa Kur'ân'ın indirilmesi durumunda onun boyun eğip itaat edeceğini bildirmektedir. ${ }^{108}$ Nitekim Bursevî, Allah'ın bütün eşyaya hayat ve manevi idrak verdiğini; Hz. Musa Rabbini görmek istediğinde Allah'ın dağa tecelli ettiğini dağın buna dayanamayıp paramparça olmasının bunun kanıtı olduğunu bildirmektedir. Evliyâ bunu görmüş, bundan mahrum kalanlar gaflete düşmüşlerdir. Kendisine Kur'ân indirilen dağ ile indirilmeyen dağ birbirinden farklı olup kendisine tecelli edilen dağ avam tarafından fark edilirken; diğeri ancak havass tarafından hissedilebilir. ${ }^{109}$

\footnotetext{
102 el-Furkân 25/32.

${ }^{103}$ Ebu'l-Fadl Reşîduddîn Ahmed b. Ebû Saîd el-Meybudî, Keşfu'l-esrâr ve uddetu'l-ebrâr, nşr. Ali Asgar Hikmet (Tahrân: Muesses-i İntişarat-i Emir-î Kebîr, 1382), 10/55-56.

104 Rûzbihân el-Baklî, 'Arâîsü'l-beyân, 3/415; Ebû Abbas Ahmed b. Muhammed b. Acîbe, el-Bahru'l-medîd fî tefsîri'lKur'âni'l-mecîd, thk. Ahmed Abdullah el-Kuraşî Reslân (Kâhire: 1999/1419),10/44.

105 Sülemî, Hakâiku't-tefsîr, 2/321.

106 İsmâil Hakkı Bursevî, Rûhu'l-beyân (Beyrut: Dâru İhyaî Turasi'l-Arabî, ts), 9/184.

${ }^{107}$ Krş.el-A'raf 7/143.

${ }^{108}$ Muhyiddîn Arabî, Muhammed b. Alî b. Muhammed, Tefsîru İbn Arabî, thk. Abdulvâris Muhammed Ali (Beyrût: Dâru'l-Kutubi'l-ïlmiyye, 2011), 2/312.

${ }^{109}$ Bursevi, Ruhu'l-beyân, 9/452.
} 
Tûr varlığın kendisidir. “Ona Tûr'un să̆ tarafindan seslendik ve onu fisıldaşırcasına (kendimize) yaklaştırdık."110ayetinde anlatılan, münacâtın yeri olan sır makamı olan kalp Tûr'unun zirvesidir. Burası vicdan denilen vahiy mahallidir Allah, Hz. Musa'yı kendisine fısıldaşan kimse kadar yaklaştırmış, ona "Kelim” adını vermiştir. Buradan sağ taraf olarak söz edilmesi onun şeref, güç, bereket bakımından daha önde olmasından kaynaklanmaktadır. Vahiy ruh âleminden, kutsal vadiden gelmektedir. ${ }^{111}$

Sûfî tefsirde dağların anası olarak kabul edilen Kaf Dağı zengin bir metafora sahiptir. Sûfîler bu konuda birbirine benzeyen açıklamalar yapmışlardır. Bu izahlar birbirini tamamlayan anlatımlar içerseler de yer yer birbirlerinden ayrıldığı görülmektedir. Nitekim Kur'ân'da "Kâf. Şanı yüce Kur'an'a yemin olsun!"112 buyrulmaktadır. Ayette geçen Kâf, dünyayı çepeçevre saran zümrüt yeşili, semanın üzerinde durduğu, göğe rengini veren, dăg silsilelerin bağlı olduğu ana dağ olarak yorumlanmıştır. ${ }^{113}$

Sûfîler bu ayetin yorumunu daha da zenginleştirmişlerdir. Tüsterî (ö. 283/896) “Dünyayı çevreleyen dağdır, Allah'ın ilk yarattı̆̆ı dağ olup “Derken (güneş batınca) onlar karanlığın perdesiyle gizlendi." ${ }^{114}$ ayetinde bahsedilen güneşin battığı yerdir. İnsan gibi bir yüze sahiptir, melekler gibi marifeti bilen bir kalbi vardır"115 demektedir. Görüldügüü gibi Tüsterî zahiri anlamın yanında işârî anlam olarak dağa, marifeti bilen kalp anlamını vererek yoruma genişlik kazandırmıştır.

Sülemî (ö. 412/1021), İbn Ata'dan nakilde bulunarak ilahi hitabı ve müşahedatı taşıması, bunların makamının yüceliğini etkilememesi dolayısıyla Kâf'ı Muhammedî kalbin kuvveti olarak yorumlamıştır. ${ }^{116}$

Abdulkâdir Geylânî (ö. 561/1165-66), Kâf'ı hilafet hilatını, ilahi niyabeti ve değerleri almak için yetkin, vahyi ve ilhamı bütün varlıklara tebliğ eden, onlara tevhit konusunda komuta eden insan-1 kâmil (Hz. Muhammed) şeklinde yorumlamaktadır. ${ }^{117}$

\footnotetext{
${ }^{110}$ Meryem 19/52.

111 Muhyiddîn Arabî, Tefsîru İbn Arabî, 2/9, 26.

112 Kâf 50/1.

113 Taberî, Câmiu'l-beyân, 21/401; Ebû İshâk Ahmed b. Muhammed b. İbrâhîm es-Sa'lebî, el-Keşf ve'l- Beyân, thk. Ebû Muhammed b. Âşûr (Beyrut: Dâru İhyaî Turasi'l-Arabî, 2002), 9/92-93.

114 Sâd 38/32.

${ }^{115}$ Ebû Muhammed Sehl b. Abdillâh b. Yûnus b. Îsâ b. Abdillâh b. Refî et-Tusterî, Tefsîrü'l-Kurâni'l-azîim, thk. Taha Abdurrauf Sa'd- Sa'd Hasen Muhammed Ali (Kahire: Dâru'l-Harem, 2004), 256.

${ }^{116}$ Muhammed b. Huseyn es-Sülemî, Hakâiku't-tefsîr, thk. Seyyid İmran (Beyrut: Dâru'l-Kutubi'l-İlmiyye, 2001), 266.

117 Muhyiddîn Abdulkâdir el-Geylânî, Tefsîru'l-Ciylânî, thk. Ahmed Ferîd el-Mizyadî (Pâkistân: el-Mektebetu'lMa'rufiyye, 2010/1431), 5/32-35.
} 
Rûzbihân b. Ebî Nasr el-Baklî (ö. 606/1209), “Allah Kâf'a yemin etmekle, her şeyin aslı olan büyüklük ve yücelik sahibi kibriyâ sıfatına yemin etmiştir" diyerek Allah'ın büyüklügünün kıdemine vurgu yapmakta, her şeyin onun sayesinde var olduğunu belirtmektedir. ${ }^{118}$

Necmüddîn-i Kübrâ (ö. 618/1221), “her sâlikin Allah'a ulaşması ve yakınlaşması için makamlar vardır. Her sâlikin kendisi için takdir edilen makama ulaşmasına Kâf ile işaret edilmiştir, adeta ona yerini bil, haddini aşma dur denilmiştir."119 diyerek Kâf'a sâlikin bulunduğu makam şeklinde açıklama getirmiştir.

İbn Arabî (ö. 638/1240), “Kâf her şeyi kuşatan, ilâhî arştan meydana gelen Muhammedî kalbe işaret etmektedir. Rabbin perdesi olduğu için kalp makamına ulaşanlar onu bilebilir ve o makama erenler bu dağı görebilir" diyerek Kâf'ı Rabbin perdesi olarak tavsif etmekte, kalp makamına ulaşanların onu görebileceğini ifade etmektedir. ${ }^{120}$

İsmâil Hakkı Bursevî (ö. 1137/1725), kendinden öncekilerin görüşlerini aktardıktan sonra Kâf Hz. Peygamberin her terkip ve oluştan uzak, biricik ve her vasıftan arî olarak onun huzurundaki kıyamına, ardından da ruhani âlemden görünen cismani makama gelmesine işaret ettiğini bildirmektedir. ${ }^{121}$

Bursevî Kâf'1 nuru Muhammedî olarak görmekte, bu nurun feyzinden bütün müminlerin yaratıldığını belirtmektedir. Ayrıca Kâf Dağı bütün dağların anası olması hasebiyle kutbu'l-aktâbın haline işaret etmektedir. Zira isminin birleştirici, kapsayıcı yönünün yanında yüksek bir dereceye sahip olması bütün ricâle önderlik etmesini sağlamaktadır. Onun sayesinde yeryüzünün sakinleri korunmaktadır. ${ }^{122}$

\section{Sonuç}

Kur'ân'da dağ kelimesi genel olarak cebel, ravâsî ve tûr kelimeleriyle ifade edilmektedir. Cebel kelimesi büyüklüğü, ihtişamı ve yüceliği anlam dairesinde barındırırken istiare yoluyla da gücü ve güçlü durmayı betimlemektedir. Ayrıca, insana büyüklenmemesi ve kibre kapılmaması için Allah'ın kudret ve azametinin timsali olarak dağlar örnek gösterilmiştir.

118 Rûzbihân b. Ebî Nasr el-Baklî, 'Arâîü'l-beyân, 3/332.

119 Necmüddîn-i Kübrâ Ahmed b. Ömer b. Muhammed, Tevîlâtü'n-Necmiyye,thk. Ahmed Ferid el-Mizyadî, (Beyrut: Dâru'l-Kutubi'l-ïlmiyye, 2009), 5/380-382.

${ }^{120}$ Muhyiddîn Muhammed b. Alî b. Muhammed el-Arabî, Tefsîru İbn Arab̂̂, thk. Abdulvâris Muhammed Ali (Beyrût: Dâru'l-Kutubi'l-İlmiyye, 2011), 2/262.

${ }^{121}$ Bursevî, Rûhu'l-beyân, 9/100.

122 Bursevi, Ruhu'l-beyân, 9/102. 
Ravâsî kelimesi sağlam ve sabit durmayı ifade etmektedir. Bu anlamıla dağların yerkürenin sarsılmaması ve üzerindekileri fırlatmaması için denge unsuru olarak tebarüz etmekte; adeta demir atmış gemideki çapa vazifesi görmektedir.

Dağ anlamına gelen Tûr kelimesi aynı zamanda kutsal dağ motifini örneklemekte, vahyin tecelli ettiği bereketli mekânlardan birisi olarak temayüz etmekte, türdeşlerinden bu yönüyle ayrılmaktadır. Değişim ve dönüşüm anlamını içinde barındırarak vahyin insan hayatına getirdiği değişim ve dönüşümle ortak paydada ve manada birleşmektedir.

Kur'ân'da dağı ifade etmek üzere kullanılan cebel ve ravâsî kelimeleri daha çok fiziki ve maddî anlamlarıyla öne çıkmakta; tûr ve râbiye kelimeleri ise maddi faydalarının yanında dağların manevî yönünü izhar etmektedirler.

Sûfî tefsirde -manevi yön olarak- dağ kelimesi metaforik anlamlar kazandığı gibi onlara kaynak da olmuştur. İlahi vahyin tecelli ettiği mekân olarak dağ ile Muhammedî kalb arasında analoji kurularak onu ifade eder hale gelmiştir. Dağ azamet ve yüksekliğin sembolü olarak salikin ulaştığı makam olarak tavsif edilmiştir. Ayrıca tasavvufun önemli kavramlarından olan, bütün müminlerin feyzinden yaratıldığına inanılan nur-u Muhammedî ile de dağ arasında irtibat kurulmuştur. İnsanın yüzü, Allah'ın cemalinin tecelli ettiği yer olarak tavsif edilmiştir.

Dağların anası olarak gösterilen Kâf Dağı kutbu'l-aktaba benzetilmiştir. Onlar yücelik ve birleştiricilik yönleriyle birbirlerine benzemektedirler. Dahası yeryüzünün sakinleri onlar sayesinde korunabilmektedir. Kâf Dağı Kibriya sıfatının tecellisi, dağların kemali olması hasebiyle de insan-1 kâmilin kendisidir.

Sonuç olarak dağ gerek dilde gerekse sûfî yorumda odak anlamına paralel olarak, ana ekseni muhafaza ederek yeni anlamlar kazanmıştır. Bu anlamlar çeşitli analojiler üzerinden kurgulanmış mistik düşüncenin ürünü olup dilin metaforik gücünden yararlanılarak elde edilmiştir. 


\section{Kaynakça}

Abdulbâki, Muhammed Fuâd. el-Mu'cemu'l-mufehres lî elfâzi Kur'âni'l- kerîm. Kâhire: Dâru'lHadîs,1364/1944.

Ahmed, Yûsuf el-Hâc. Mevsuatu el-İ'cazu'l-İlmi fi'l-Kur'âni'l-Kerim ve's-Sunneti'l-Mutahharati. Dimaşk: Mektebetu İbn Hacer, 2003.

Alûsî, Ebû̀'s-Senâ Şehâbeddîn Mahmûd b. Abdullâh b. Mahmûd. Ruhu'l-meânî fî tefsîri'lKur'âni'l-âzim ve's-seb'i'l-mesânî. thk. Mâhir Habbûş. 30 Cilt. Beyrut: Muessesetu'rRisâle, 2010.

Askerî, Ebû Hilâl. el-Furûku'l-luğaviyye. thk. Muhammed İbrâhîm Selîm. Kâhire: Dâru'l-i̇lm ve's-Sekâfe, 1997.

Baş, Mustafa. “Dağ Kültü”. Çukurova Üniversitesi İlahiyat Fakültesi Dergisi 13/1 (Ocak-Haziran, 2013), 165-179.

Begavî, Ebû Muhammed el-Huseyn b. Mes'ûd b. Muhammed. Me'âlimu't-tenzîl. thk. Muhammed Abdullah en-Nahr vd. 8 Cilt. Riyâd: Dâru Taybe, 1412/1991.

Bursevî, İsmâil Hakkı. Rûhu'l-beyân. 10 Cilt. Beyrut: Dâru İhyaî Turâsi'l-Arabî, ts.

Cebel, Muhammed Hasen Hasen. el-Mu'cemu'l-iştikâkîyyi'l-muassal li elfâzi'l- Kur'âni'l-kerim. Kâhire: Mektebetu'l-Âdâb, 2010.

Cevâlîkî, Ebû Mansûr Mevhûb b. Ahmed b. Muhammed. el-Mu'arreb mine'l-kelâmi'l-a'cemî 'alâ hurûfi'l-mu 'cem. thk. F. Abdurrahîm. Dımaşk: Dâru'l-Kalem, 1410/1990.

Derveze, Muhammed İzzed. Tefsîru'l-Hadîs. 10 Cilt. Beyrût: Dâru'l- Ğarbi'l-İslâmî, 2. Basım, $1421 / 2000$.

Eck, Diana L. “Mountain”. Encyclopedia of Religion. ed. Mircea Eliade. 10 Cilt. New York: Macmillan Publishing Company, 1987, 10/130-134.

Efendi, Hasîrîzâde Elîf. en-Nûru'l-Furkân fî şerhi lugati'l-Kur'ân. 2 Cilt. İstanbul: Türkiye Yazma Eserler Kurumu Başkanlığı Yayınları, 2015.

Ferâhîdî, Halîl b. Ahmed. Kitâbu'l- 'Ayn. thk. Abdulhamîd Hindâvî. 4 Cilt. Beyrut: Daru'lKutubi'l-ìlmiyye, 2003.

Fîrûzâbâdî, Mecduddîn Muhammed b. Ya'kûb b. Muhammed. Besâ'iru zevi't-temyîz fì letâ' 'ifi'l-kitâbi'l- 'azîz. thk. Muhammed Alî en-Neccâr. 6 Cilt. Kahire: el-Meclisu'l-Â'lâ li Şuûni'l-İslamiyye, 3.Basım, 1416/1996.

Fîrûzâbâdî, Mecduddîn Muhammed b. Ya'kûb b. Muhammed. Kâmûsu'l- muhit. Kahire: Dâru'l-Hadîs, 1429/2008.

Geylânî, Muhyiddîn Abdulkâdir. Tefsîru'l-Ciylânî. thk. Ahmed Ferîd el-Mizyadî. 5 Cilt. Pâkistân: el-Mektebetu'l-Ma'rufiyye, 1431/2010.

Gül, Ahmet. Kur'an'da Kutsallı. Saarbrücken: Türkiye Alim Kitapları, 2014.

Harman, Ömer Faruk. "Dağ", Türkiye Diyanet Vakfı İslam Ansiklopedisi. 8 Cilt. İstanbul: TDV Yayınları, 1993.

Hâzin, Ebu'l-Hasen Alâuddîn Alî b. Muhammed b. İbrâhîm. Lubâbu't-te 'vîl fî̀ me 'âni't-tenzîl. thk. Abdusselâm Alî Şâhîn. 4 Cilt. Beyrût: Dâru'l-Kutubi'l-İlmiyye, 1425/2004.

İbn Âdil, Ebû Hafs Ömer b. Alî ed-Dimaşkî. el-Lubâb fí İlmi'l-Kitâb. thk. Âdil ahmed Abdumevcûd- Alî Muhammed Muavvid. 20 Cilt. Beyrût: Dâru'l-Kutubi'l-İlmiyye, 1419/1998.

İbn Aşûr, Muhammed Tâhir. et-Tahrîr ve't-Tenvîr. 30 Cilt. Tûnus: ed-Dâru't-Tûnusiyye, 1984.

İbn Fâris, Ebû'l-Huseyn Ahmed. Mekâyîsu'l-luğa. thk. Abdusselam Muhammed Hârûn. 6 Cilt. Beyrut: Dâru'l-Fikr, 1979.

İbn Kesîr, Ebu'l-Fidâ' İsmâîl b. Ömer. Tefsîrü'l-Kur'âni'l-'azîm. thk.Mustafa Seyyid Muhammed vd. 15 Cilt. Ciza: Muessesetu Kurtubâ, 2000. 
İbn Manzûr, Ebü'l-Fazl Cemâlüddîn Muhammed b. Mükerrem b. Alî b. Ahmed el-Ensârî. Lisânü'l- 'Arab. thk. Abdullah Ali-Muhammed Ahmed- Hâşim Muhammed. 55 Cilt. Kâhire: Dâru'l-Meârif, ts.

İbn Sîde, Ebu'l-Hasen Alî b. İsmâîl ed-Darîr el-Mürsî. el-Muhkem ve'l-muhîtu'l-a żam. thk. Abdulfettâh es-Seyyid Selîm- Faysal el-Hafyân. 12 Cilt. Kahire: Ma'hedu'lMahtutâti'l-Arabiyye, 2. Basım, 2003.

İzbırak, Reşat. Coğrafya Terimleri Sözlü̆̆̈̈̈. İstanbul: MEB Yayınları, 1992.

Jeffery, Arthur. The Foreign Vocabulary of The Qur'an. Leiden: Brill, 2007.

Karaman, Hayreddin vd.. Kur'an Yolu Türkçe Meal ve Tefsir. 5 Cilt. Ankara: TDV Yayınları, 2012.

Kebîsî, Ahmed Ubeyd. Mevsûatu'l-kelimeti ve ehavâtihâ fi'l-Kur'âni'l-kerim. 12 Cilt. Beyrût: Dâru'l-Marife, 1438/2017.

Kurtubî, Ebû Abdillah Muhammed b. Ahmed. el-Câmi li-ahkâmi'l-Kur'ân. thk. Abdullah b. Abdulmuhsin et-Turkî. 24 Cilt. Beyrut: Muessesetu'r-Risâle, 2006.

Kutub, Seyyid. Fî Zilâli'l-Kur'ân. 6 Cilt. Kâhire: Dâru'ş-Şurûk, 32. Basım, 2003.

Meybudî, Ebu'l-Fadl Reşîduddîn Ahmed b. Ebû Saîd. Keşfu'l-esrâr ve 'uddetu'l-ebrâr. nşr. Ali Asgar Hikmet. 10 Cilt. Tahrân: Muesses-i İntişarat-i Emir-î Kebîr, 7.Basım, 1382/1962.

Muhyiddîn Arabî, Muhammed b. Alî b. Muhammed. Tefsîru İbn Arabî. thk. Abdulvâris Muhammed Ali. 2 Cilt. Beyrût: Dâru'l-Kutubi'1-İlmiyye, 2011.

Mukâtil b. Süleymân. Tefsîru Mukâtil b. Süleymân. thk. Abdullah Mahmûd Şehhâte. 5 Cilt. Beyrut: Muessesetu Tarîhu'l-Arabî, 2002.

Muslih, Abdullah b.Abdulazîz- es-Savî, Abdulcevâd. el-í'cazu'l-ilmî fi'l-Kur'ân ve's-sunne. Cidde: Darû Ciyâd, 1429/2008.

Nâblusî, Muhammed Râtıb. Mevsûatu'l-i'cazu'l-ilmî fi'l-Kur'ân ve's-sunneti. Dımaşk: Dâru'lMektebi, 2. Bask1, 1426/2005.

Naggar, Z.R. The Geological concept of mountain in the Qur'an. Cairo: Al-Falah Foundation, $1424 / 2003$.

Neccâr, Zağlûl. Tefsîru'l-ayâti'l-kevniyyeti fi'l-Kur'âni'l-kerîm. 4 Cilt. Kâhire: Mektebetu'ş-Şurûk ed-Duveliyye, 1428/2007.

Necmüddîn-i Kübrâ, Ahmed b. Ömer b. Muhammed. Te'vîlâtü̈n-Necmiyye. thk. Ahmed Ferid el-Mizyadî. 6 Cilt. Beyrut: Dâru'1-Kutubi'l-i̇lmiyye, 2009.

Öztürk, Mustafa. İlahî Hitabın Tefsiri. 2 Cilt. Ankara: Ankara Okulu Yayınları, 2020.

Râgıb el-İsfahânî, Ebü'l-Kāsım Hüseyn b. Muhammed b. el-Mufaddal. Müfredâtu elfâzi'lKur'ân. thk. Safvan Adnan Davudî. Dımaşk: Dâru'l-Kalem, 2009.

Râzî, Fahrûddîn Muhammed b. Ömer. Mefâtîhu'l-Gayb. 32 Cilt. Beyrut: Dâru'l-Fikr, 1981.

Razî, Muhammed b. Ebî Bekr b Abdulkadir. Muhtâru's-Sihâh. Beyrut: Mektebetu Lubnân, 1986.

Rûzbihân el-Baklî, Ebû Muhammed Sadrüddîn b. Ebî Nasr. 'Arâisü̈ll-beyân fî hakâîki'l-Kur'ân. thk. Ahmed Ferîd el-Mizyadî. 3 Cilt. Beyrut: Dâru'l-Kutubi'l-i̇lmiyye, 2008.

Sa'lebî, Ebû İshâk Ahmed b. Muhammed b. İbrâhîm en-Nîsâbûrî. el-Keşf ve'l-beyân. thk. Ebû Muhammed b. Âşûr. 10 Cilt. Beyrut: Dâru İhyaî Turasi'l-Arabî, 2002.

Saçlı, Merve. "Bakara Suresi 74.Ayet Bağlamında Taşlar ve Allah Korkusu”. Şırnak Üniversitesi İlahiyat Fakültesi Dergisi 11/24 (Haziran 2020), 325-345.

Sarıkçıŏlu, Ekrem. Din Fenomenolojisi. Isparta: Fakülte Kitabevi, 2002.

Schwartz, Baruch J. "Sinai Mount", The Oxford dictionary of Jewish religion, ed. R. J. Zwi Werblowsky. New York: Oxford University Press,1997.

Seligsohn, Max. "Sinai, Mount", The Encyclopedia of Jewish, ed. Isidore Singer. 12 Cilt. London: Funk\&Wagnalls Company, 1912. 
Sinanoğlu, Mustafa. "Sînâ". Türkiye Diyanet Vakfı İslam Ansiklopedisi. 37/ 221-222. İstanbul: TDV Yayınları, 2009.

Sülemî, Muhammed b. Huseyn. Hakâiku't-tefsîr. thk. Seyyid İmran. Beyrut: Dâru'1-Kutubi'lİlmiyye, 2001.

Suyûtî, Celâluddîn Abdurrahmân b. Ebî Bekr b. Muhammed. ed-Durru'l-mensûr fi't-tefsîr bi'lme'sûr. thk. Abdullah b. Abdulmuhsin et-Turkî. 17 Cilt. Kahire: Hicr, 2003.

Taberî, Ebû Cafer Muhammed b. Cerîr. Câmiu'l-beyân an te'vili ayi'l-Kur'ân. thk. Abdullah Abdulmuhsin et-Turkî. 27 Cilt. Kâhire: Hicr, 2001.

Tüsterî, Ebû Muhammed Sehl b. Abdillâh b. Yûnus b. Îsâ b. Abdillâh b. Refî̀. Tefsîrü'lKur'âni'l-'azîm. thk. Taha Abdurrauf Sa'd- Sa'd Hasen Muhammed Ali. Kahire: Dâru'l-Harem, 2004.

Zemahşerî, Ebu'l-Kasım Mahmûd b. Ömer b. Muhammed. el-Keşşâf hakâa'iḳi ğavâmizi't-tenzîl ve 'uyûni'l-ekârvîl fî̀ vücûhi't-te'vîl. thk. Adil Abdulmevcûd- Ali Muhammed elMuavvid. 6 Cilt. Riyâd: Mektebetu Ubeykân, 1998. 